\title{
Neck and Low Back Pain Among Dentistry Staff
}

\section{Diş Hekimliği Fakültesi Çalışanlarında Bel ve Boyun Ağrıları}

\author{
Duygu Geler Külcü1 ${ }^{1}$ Gülçin Gülşen ${ }^{1}$, Tuba Çiğdem Altunok², Davut Küçükoğlu³, Sait Naderi4 \\ 1Yeditepe Üniversitesi Tıp Fakültesi, Fiziksel Tıp ve Rehabilitasyon Anabilim Dalı, istanbul, Turkey \\ 2Yeditepe Üniversitesi Tıp Fakültesi, Biyoistatistik Anabilim Dalı, istanbul, Turkey \\ 3Yeditepe Üniversitesi Diş Hekimliği Fakültesi, istanbul, Turkey \\ 4Ümraniye Eğitim ve Araştırma Hastanesi, Beyin Cerrahisi Anabilim Dalı, istanbul, Turkey
}

\begin{abstract}
Objective: To assess low back pain (LBP) and neck pain (NP) frequency in dentistry personel and to assess associated factors with LBP and NP in dentistry.

Materials and Methods: 206 subjects participated in this crosssectional study. Demographic properties, working conditions, NP and LBP frequency in several positions have been recorded. Subjects were assessed by Visual analogue scale (VAS) (0-10) pain scores, Neck Pain Disability Index (NPDI) and Roland-Morris LBP Questionnaire (RMQ). The relationship between working conditions and assessed parameters has been analyzed by Spearman correlation coefficient $(0<r<1)$. Comparison between age groups (age below and above 25 yrs) were assessed by Student $T$ test, Mann Whitney $U$ test and chi-square test. Comparison among specialization groups were assessed by Kruskal-Wallis variance analysis and chi-square test.

Results: Mean age of the subjects was $23.5 \pm 5.0$ ( $57 \%$ female). There were correlations between weekly working hours and LBP frequency during standing $(r=0.153)$ and walking $(r=0.178)$, daily working hour and LBP frequency during walking $(r=0.159)$. Duration worked at chair-side was inversely correlated with RMQ $(r=-0.188)$ and NDI $(r=0.271)$ scores. Duration worked by standing was related with RMQ $(r=0.252)$, NDI $(r=0.334)$, LBP $(r=0.200)$ and NP-VAS scores $(r=0.279)$. Duration worked by standing was related with NP and LBP frequency in all positions. There was no difference among specializations. NDI scores were higher in patients older than 25 years $(p=0.043)$ but no difference was observed in terms of other parameters.

Conclusion: Working duration and posture have important influences on NP and LBP in dentistry.

(Turk J Rheumatol 2010; 25: 122-9)

Key words: Low back pain, neck pain, dentistry, disability
\end{abstract}

Received: 11.10 .2008

Accepted: 27.01.2009

\section{Özet}

Amaç: Diș Hekimliği Fakültesi çalıșanlarında bel ve boyun ağrısı sıklığını saptamak ve bel ve boyun ağrısına etki eden faktörleri araștırmaktır.

Yöntem ve Gereçler: Bu kesitsel çalıșmaya 206 kiși alındı. Demografik özellikler, çalıșma pozisyon ve süreleri, çeșitli pozisyonlarda bel ve boyun ağrısı sıklığı kaydedildi. Vizüel analog skala'ya göre (VAS) (0-10) ağrı skorları, Boyun Ağrısı Özürlülük Anketi (BAÖA) ve Roland-Morris Bel Ağrısı Anketi (RMA) ile kișilerin ağrı ve özürlülük düzeyi belirlendi. Calıșma koșulları ile değerlendirme parametreleri arasındaki ilișki Spearman korelasyon katsayısıyla $(0<r<1)$, yaș grupları arasındaki fark ( 25 yas üstü ve 25 yas altı) Student T Testi,Mann Whitney $U$ testi ve ki-kare testiyle, uzmanlık alanlarına göre gruplar arasındaki fark KruskalWallis varyans analizi ve ki-kare testiyle değerlendirildi.

Bulgular: Katılımcıların ortalama yașı $23.5 \pm 5,0$ yıldı (\%57 kadın). Haftalık çalıșma saatiyle ayakta ve yürürken bel ağrısı sıklığı arasında (sırasıyla $r=0.153$ ve $r=0.178$ ) ve günlük çalıșma saatiyle yürürken bel ağrısı sıklığı arasında pozitif ilișki saptandı $(r=0.159)$. Oturarak çalıșma süresiyle RMA ( $r=-0.188)$, ve BAÖA $(r=-0.271)$ skorları arasında ters ilișki saptandı. Ayakta çalıșma süresiyle RMA $(r=0.252)$, BAÖA $(r=0.334)$, bel ve boyun-VAS skorları (sırasıyla $r=0.200$ ve $r=0.279$ ) arasında pozitif ilișki saptandı. Ayakta çalıșma süresiyle tüm pozisyonlarda bel ve boyun ağrısı sıklığı arasında ilișki saptandı.Uzmanlık alanlarına göre gruplar arasında fark saptanmadı. 25 yaș üzeri grubun BAÖA değerleri anlamlı olarak daha yüksek saptandı $(p=0,043)$ fakat diğer parametreler açısından fark saptanmadı.

Sonuç: Çalıșma süresi ve pozisyonu, bel ve boyun ağrısı üzerinde önemli etkiye sahiptir.

(Turk J Rheumatol 2010; 25: 122-9)

Anahtar sözcükler: Bel ağrısı, boyun ağrısı, diș hekimliği, özürlülük

Alındığı Tarih: 11.10.2008 Kabul Tarihi: 27.01.2009 


\section{Introduction}

Locomotor system disorders are frequently seen in dentistry (1). It is known that the most painful regions are the cervical and lumbar spine $(2,3)$. Factors associated with professional work may predispose to back and neck pain. On account of the narrow visual field of the oral cavity, having to work with a limited scope of movement constitutes high risks for lowback and neck pain (4). It has been demonstrated that tensely maintained asymmetric body posture is a risk for lowback pain (LBP); and prolonged static neck position and repeated movements are work-related risk factors for neck pain $(5,6)$.

In the light of these findings, the aim of this study, is to investigate the risk factors associated with lowback and neck pain in dentistry. The second aim of this study is to maintain an opinion about prevelance of LBP and neck pain among dentists, students and nurses in dendistry by this study sample.

\section{Materials and Methods}

This cross sectional investigation was planned among the dentists, students and nurses in the Faculty of Dental Medicine of Yeditepe University. Those who had back and neck pain before joining the Faculty of Dental Medicine were excluded from the study as the investigation was focused on effects of conditions and postures on LBP and neck pain. A total of 206 people completed the study. The participitants signed informed consent forms. The study was approved by the ethical committee of the university.

Data were collected by means of a special questionnaire (SQ) designed by the research team, and the use of the Neck Pain Disability Index (NPDI), Roland-Morris Disability Questionnaire (RMQ), and the Visual Analoge Scale (VASscores 0-10).

\section{Special Questionnnaire Form (SQ)}

This form consists of demographic details (age, gender, height, body weight, marital status, years at work, physical exercise, cigarette smoking), four questions about routinely maintained work positions and on durations (i.e., working while sitting and working while standing (min/day), the frequency of breaks /day and break duration (min/day), and the weekly and daily working hours), six questions on the experience of LBP and neck pain in specific working positions (i.e., frequency of LBP experienced on a normal day while sitting, frequency of LBP experienced while walking, frequency of stiffness of the neck, frequency of neck pain when looking upwards-downwards, frequency of neck pain during work above the level of the head).

These questions were scored according to the Likert Scale with 5 points on 'never', rarely', sometimes', 'most times' and 'at all times'. In order to give the final form, the SQ was tried out for practicability and understandability on 3 randomly selected dentists.

\section{Neck Pain Disability Index (NPDI)}

This questionnaire has been widely used and accepted in evaluating the level of disability in patients with neck pain (7). It consists of 10 parts, seven of which are concerned with daily activities, two parts with pain, and one with concentration problems. Each part presents a choice of 5 scores (0-5), the total score being expressed interms of percentage of the whole with the high values respresenting a higher degree of disability. The reliability and validity of Turkish version of the NPDI has been demonstrated (8).

Roland-Morris LBP and Disability Questionnaire (RMQ)

This is an individaully completed questionnaire that consists of 24 questions with high scores respresenting high degree of disability (9). Its reliability, validity and sensitivity to changes in time has been shown. The reliability and validity of the Turkish version has been demonstated (10).

\section{Statistical Analysis}

The SPSS 15.0 package program (Chicago, IL, USA) was used. Statistical analysis were done by a biostatistics expert. Statistical significance was accepted for $P$ values below 0.05 . The relationships between the experimental parameters and the existing working conditions were evaluated on the basis of the Spearman coefficient. Any differences between the data on experimental parameters based on the professional speciality of the dentists and the demographic details were assessed by the KruskalWallis variation analysis and the chi-square test. Dividing the experimental subjects into two groups, as those below and above the age of 25 years, the differences between the data on the experimental parameters with respect to age were computed using the Student t test, Mann-Whitney $U$ test and the chi-square test.

\section{Results}

Of the participatants in this investigation, $27 \%$ were dentists specialised in the disciplines of orthodontics, orthognathic surgery, endodonty, periodonty, prosthodontics and paediatric dentistry; $37 \%$ were early phase students from the first three years of training; $23 \%$ were students from the $4^{\text {th }}$ and $5^{\text {th }}$ year of training; and $13 \%$ were nurses.

\section{Demographic details (Table 1)}

About half $(57 \%)$ of the participants were female with a mean age of $23,5 \pm 5,0$ years (range $=18-47$ yrs.). Demographic ditails were presented in Table 1. 


\section{Back and neck pain frequency}

The prevalence of LBP and neck pain among the participants were $61 \%$ and $34 \%$, respectively. The frequency scores of LBP and neck pain $n$ have been presented in Figure 1.

\section{Exprimental parameters}

The VPS scores for LBP and neck pain, the NPDI scores and the RMQ scores have been shown in Table 1.

Comparisons of the experimetal parameters and the demographic details on the basis of age groups

The participatants were divided into two groups; above and below the age of 25 years. The cut-off value was selected as 25 since the more actively working group, consisting of the specialised dentisits and postgraduate students, were expected to be in the former group, and the remaining trainees were expected to be in the latter group. When compared on this basis of age difference, only the NPDI scores were found to be significantly higher $(p=0.043)$ in the group above the age of 25 . No significant differences were observed in the other experimental parameters.

Table 1. Demographic properties and working conditions

\begin{tabular}{|c|c|c|}
\hline & & $\mathrm{n}=\mathbf{2 0 6}$ \\
\hline \multicolumn{2}{|c|}{ mean SD } & $23.5 \pm 5.0$ \\
\hline \multicolumn{2}{|l|}{ Gender } & $57 \%$ bayan \\
\hline \multicolumn{2}{|c|}{ Body mass index $\left(\mathrm{kg} / \mathrm{m}^{2}\right)$ mean SD } & $22.1 \pm 3.3$ \\
\hline \multicolumn{2}{|c|}{ FDM years of work } & $4.9 \pm 5.2$ \\
\hline \multirow[t]{4}{*}{ Groups } & First three years students & 76 \\
\hline & $4^{\text {th }}$, and $5^{\text {th }}$, years students & 48 \\
\hline & Nurses & 26 \\
\hline & Dentists & 56 \\
\hline \multicolumn{2}{|c|}{ Regular aerobic exercise habit } & $46 \%$ \\
\hline \multicolumn{2}{|c|}{ Smoking } & $19 \%$ \\
\hline \multicolumn{2}{|c|}{ Daily working hour mean SD } & $4.9 \pm 4.0$ \\
\hline \multicolumn{2}{|c|}{ Weekly working hour mean SD } & $25.9 \pm 21.3$ \\
\hline \multicolumn{2}{|c|}{ Duration of work while sitting (min) mean SD } & $149.5 \pm 16.4$ \\
\hline \multicolumn{2}{|c|}{ Duration of work while standing ( $\mathrm{min}$ ) mean SD } & $73.4 \pm 14.3$ \\
\hline \multicolumn{2}{|c|}{ Duration of break (min) mean SD } & $12.1 \pm 1.2$ \\
\hline \multicolumn{2}{|c|}{ Frequency of break/ day mean SD } & $2.3 \pm 0.3$ \\
\hline \multicolumn{2}{|c|}{ LBP-VAS mean SD } & $2.9 \pm 0.3$ \\
\hline \multicolumn{2}{|c|}{ Neck-VAS mean SD } & $2.5 \pm 0,2$ \\
\hline \multicolumn{2}{|c|}{ RMQ score median (min-max) } & $0(0-18)$ \\
\hline \multicolumn{2}{|c|}{ NPDI score median (min-max) } & $12(0-60)$ \\
\hline
\end{tabular}

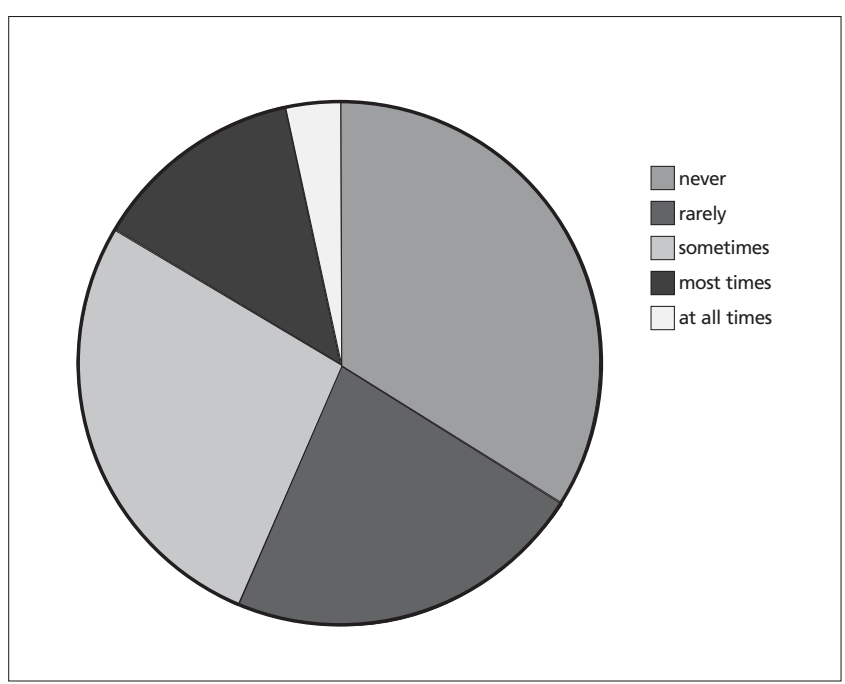

Figure 1a. Low Back Pain frequency while walking (42\%)

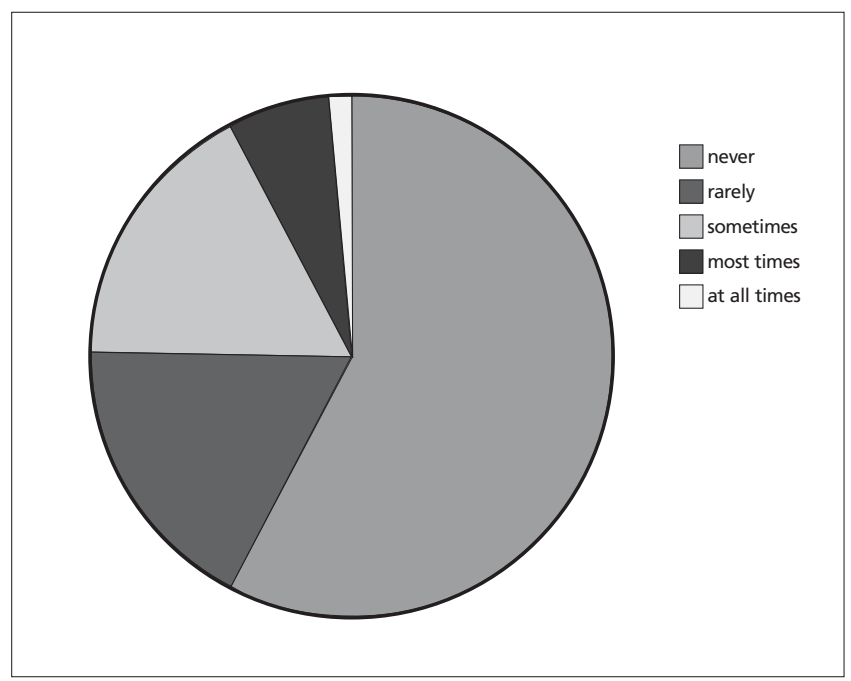

Figure 1b. Low Back Pain frequency while standing (66\%)

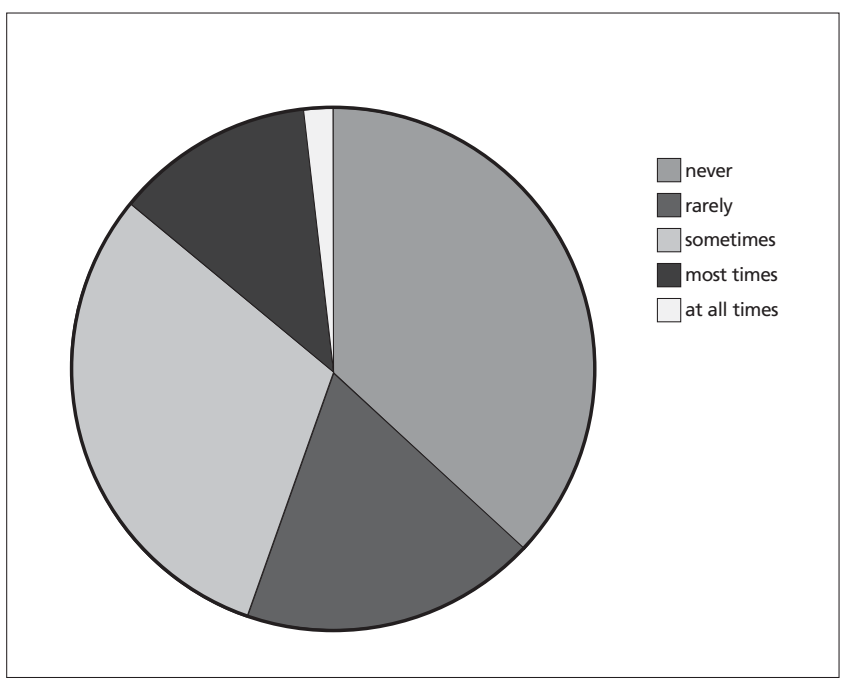

Figure 1c. Low Back Pain frequency while sitting (63\%) 


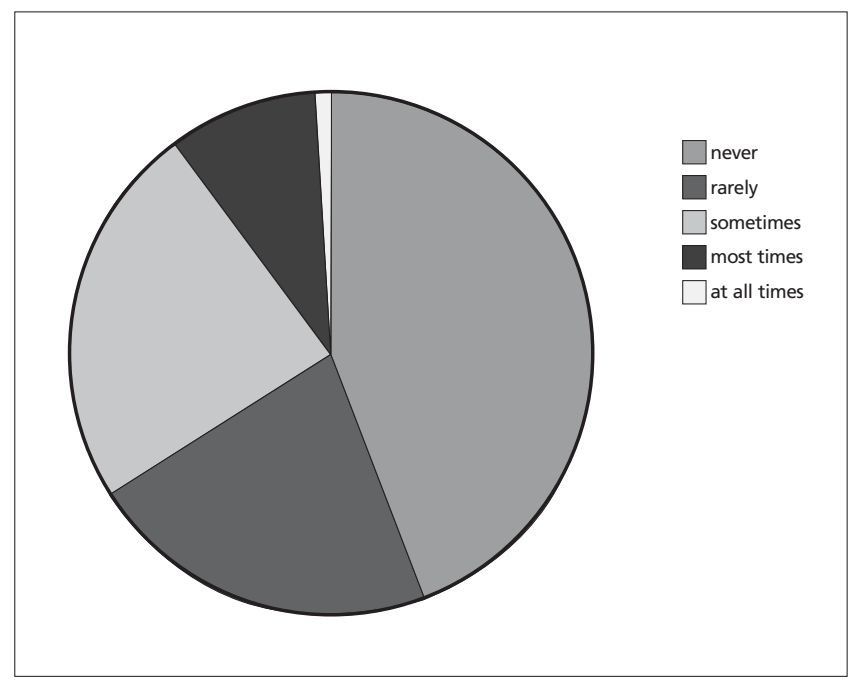

Figure 1d. Neck stiffness frequency (56\%)

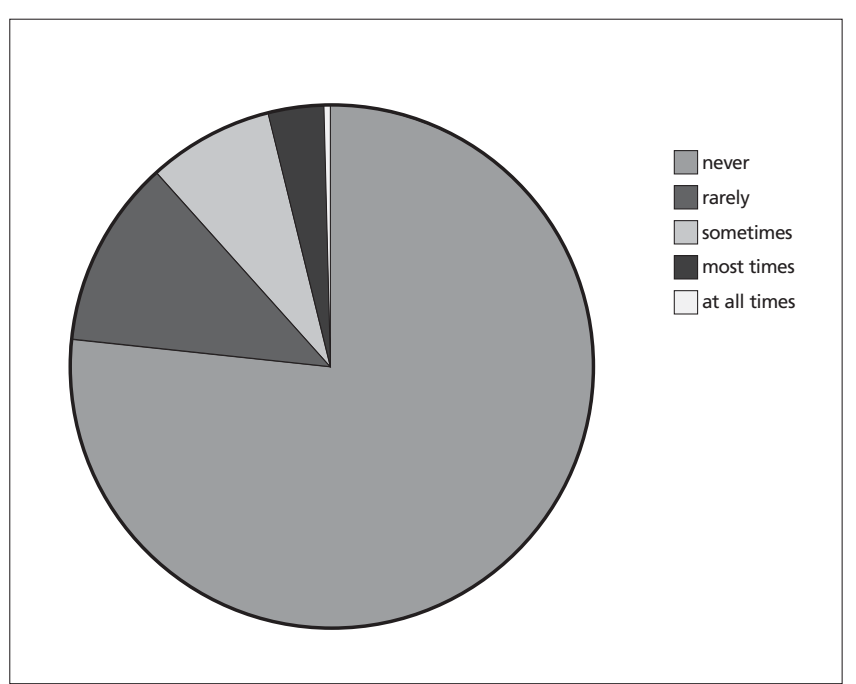

Figure 1e. Neck pain frequency while looking upwards or downwards $(23 \%)$

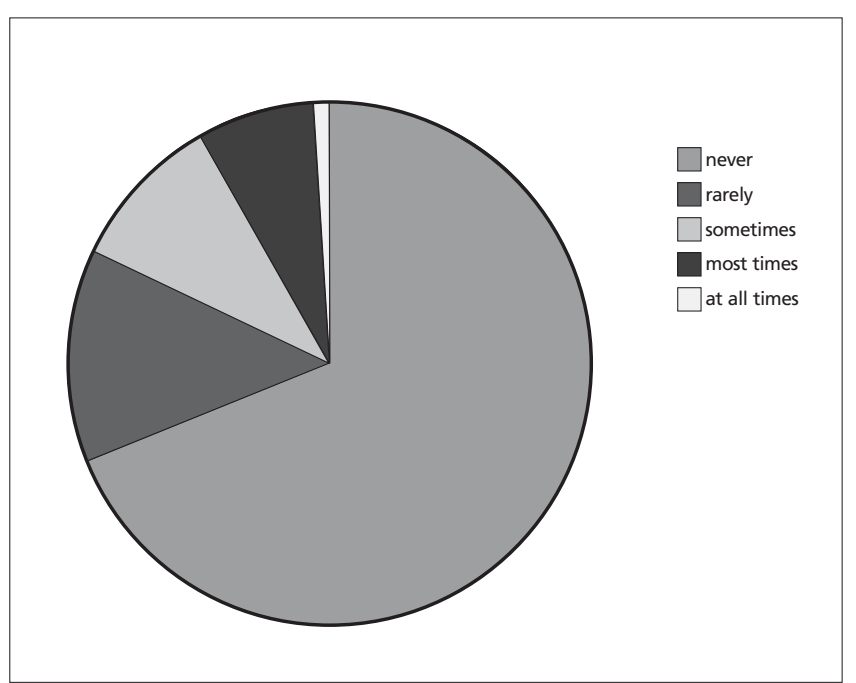

Figure 1f. Neck pain frequency durign work above the head level (31\%)
With respect to the specific demographic details, the scores on 'years at work', 'daily and weekly work hours', 'duration of breaks', 'duration of work sitting and standing' were signifciantly higher in the group with age above 25 years (Table 2 ).

Comparisons of the experimental parameters and the demographic details on the basis of professional specialisation

Dentisits were grouped according to the areas of professional specialisation. No differences were found in the data on the experimental parameters on the basis of this grouping or on the basis of the demographic details (Table 3).

Relationship between the working conditions and the experimental parameters

Significant inverse correlation was determined between the SQ data on working while sitting and the RMQ scores $(r=-0.188, p=0.008)$ and the NPDI scores $(r=-0.271, p=0.000)$.

Significant positive correlations were determined between the SQ data on working while standing and the RMQ scores $(r=0.252, p=0.000)$, and the NPDI scores $(r=0.334, p=0.000)$ and the VAS scores for neck pain $(r=0.279, p=0.000)$ and $\operatorname{LBP}(r=0.200, p=0.005)$ (Table 4).

Relationship of working conditions and frequencies of LBP and neck pain

Positive correlations were observed in the SQ data between weekly work hours and the frequency of LBP while standing $(r=0.153, p=0.029)$ and the frequency of LBP while walking $(r=0.178, p=0.011)$; and between hours of daily work and the frequency of LBP while walking $(r=0.159, p=0.023)$.

Positive correlations were present between the duration of working while standing and the frequency of LBP while standing $(r=0.310, p=0.000)$, the frequency of LBP while walking $(r=0.240, p=0.001)$, the frequency of LBP while sitting $(r=0.171, p=0.018)$, frequency of neck stiffness $(r=0.241, p=0.001)$, the frequency of neck pain when looking upwards and downwards ( $r=0.308$, $\mathrm{p}=0.000$ ), and the frequency of neck pain while working at levels above the head $(r=0.258, p=0.000)$. An inverse correlation was observed between working while sitting and the freqency of LBP while sitting $(r=-0.146, p=0.041)$, (Table 5).

\section{Discussion}

In this study, the frequency and intensity of back and neck pain and the associated factors have been presented. In previously conducted investigations outside Turkey, 
Table 2. Comparison of age groups

\begin{tabular}{lccc}
\hline & Belove 25 years & Above 25 years & p \\
\hline Gender & $57 \%$ female & $56 \%$ female & 0,549 \\
FDM years of work median (min-max) & $2(1-9)$ & $9(4-33)$ & 0.000 \\
Body mass index $\left(\mathrm{kg} / \mathrm{m}^{2}\right.$ ) mean SD & $21.8 \pm 3.0$ & $22.8 \pm 3.7$ & 0.128 \\
Regular aerobic exercise habit & $48 \%$ & $39 \%$ & 0.164 \\
Smoking & $16 \%$ & $24 \%$ & 0.089 \\
Daily working hour median (min-max) & $1(0-12)$ & $8(2-12)$ & 0.000 \\
Weekly working hour median (min-max) & $7(0-70)$ & $44(12-84)$ & 0.000 \\
Duration of break median (min-max) & $10(0-60)$ & $10(0-60)$ & 0.723 \\
Duration of work while sitting median (min-max) & $50(0-660)$ & $240(0-720)$ & 0.000 \\
Duration of work while standing (min) mean SD & $52.7 \pm 12.3$ & $127.2 \pm 17.6$ & 0.001 \\
RMQ score median (min-max) & $0(0-18)$ & $0(0-14)$ & 0.207 \\
NPDI score median (min-max) & $10(0-60)$ & $14(0-60)$ & 0.043 \\
LBP-VAS mean SD & $3.2 \pm 2.9$ & $2.4 \pm 0.3$ & 0.107 \\
Neck-VAS median (min-max) & $2(0-9)$ & $2(0-8)$ & 0.519
\end{tabular}

1: FDM: Faculty of Dental Medicine, 2. RMQ: Roland Morris Lowback Pain and Disability Questionnaire, 3: NPDI: Neck Pain and Disability Index 4: VAS: Visual Analog Scale, Values show mean \pm SD or median (min-max)

Table 3. Comparison of groups according to specialities

\begin{tabular}{|c|c|c|c|c|c|c|c|}
\hline & $\begin{array}{l}\text { Drthognatic surgery } \\
\qquad \mathrm{n}=5\end{array}$ & $\begin{array}{l}\text { Orthodontics } \\
n=16\end{array}$ & $\begin{array}{c}\text { Periodonty } \\
n=7\end{array}$ & $\begin{array}{l}\text { Prosthodontics } \\
\mathrm{n}=17\end{array}$ & $\underset{n=4}{\text { Endodonty }} F$ & $\begin{array}{c}\text { Paediatric dentistry } \\
\mathrm{n}=7\end{array}$ & $p$ \\
\hline Gender & $40 \%$ & $50 \%$ & $57 \%$ & $59 \%$ & $0 \%$ & $57 \%$ & 0.414 \\
\hline Age (year) & $25(24-36)$ & $27.5(24-39)$ & $28(25-34)$ & $28(23-47)$ & $25.5(24-36)$ & $25(23-35)$ & 0.231 \\
\hline $\begin{array}{l}\text { FDM years of work } \\
\text { median (min-max) }\end{array}$ & $9(5-12)$ & $9(6-22)$ & $11(7-17)$ & $9(5-33)$ & $7(5-9)$ & $7(5-17)$ & 0.259 \\
\hline $\begin{array}{l}\text { Body mass index } \\
\left(\mathrm{kg} / \mathrm{m}^{2}\right) \text { median (min-max) }\end{array}$ & $23.7(20.3-26.8)$ & $21.7(17.5-32.3)$ & $22.9(19.4-28.5)$ & $20.8(17.4-30.0)$ & $25.9(17.6-26.2)$ & $22.8(19.1-33.9)$ & 0.885 \\
\hline $\begin{array}{l}\text { Regular aerobic } \\
\text { exercise habit }\end{array}$ & $40 \%$ & $63 \%$ & $29 \%$ & $41 \%$ & $25 \%$ & $43 \%$ & 0.615 \\
\hline Smoking & $0 \%$ & $6 \%$ & $29 \%$ & $18 \%$ & $25 \%$ & $43 \%$ & 0.285 \\
\hline $\begin{array}{l}\text { Daily working hour } \\
\text { median (min-max) }\end{array}$ & $9(8-12)$ & $11(7-14)$ & $8(4-12)$ & $8(4-12)$ & $7.5(7-11)$ & $7(4-12)$ & 0.134 \\
\hline $\begin{array}{l}\text { Weekly working hour } \\
\text { median (min-max) }\end{array}$ & $50(40-65)$ & 60 (35-77) & $40(20-70)$ & $45(20-84)$ & $41(35-65)$ & $36(24-65)$ & 0.293 \\
\hline $\begin{array}{l}\text { Duration of break } \\
\text { median (min-max) }\end{array}$ & $10(10-15)$ & $10(0-60)$ & $5(0-15)$ & $5(0-30)$ & $5(0-15)$ & $5(0-30)$ & 0.423 \\
\hline $\begin{array}{l}\text { Duration of work while } \\
\text { sitting median (min-max) }\end{array}$ & $470(120-600)$ & $85(0-720)$ & $300(180-600)$ & $360(120-540)$ & $420(60-420)$ & $360(280-480)$ & 0.197 \\
\hline $\begin{array}{l}\text { Duration of work while } \\
\text { standing median (min-max) }\end{array}$ & $60(0-120)$ & $200(0-360)$ & $120(120-120)$ & $120(0-360)$ & $300(300-300)$ & $60(0-120)$ & 0.172 \\
\hline RMQ score median (min-max) & ax) $5(0-10)$ & $0(0-49$ & $0(0-1)$ & $0(0-14)$ & $0.5(0-1)$ & $0(0-4)$ & 0.871 \\
\hline NPDI score median (min-max) & ax) $6(0-28)$ & $4(0-20)$ & $10(4-22)$ & $14(0-44)$ & $10(4-30)$ & $2(0-12)$ & 0.124 \\
\hline LBP-VAS median (min-max) & $2.5(0-9)$ & $1.5(0-5)$ & $1(0-7)$ & $1(0-6)$ & $1.5(1-6)$ & $3(0-4)$ & 0.988 \\
\hline Neck-VAS median (min-max) & $0(0-6)$ & $1.5(0-7)$ & $2(0-5)$ & $2(0-8)$ & $4.5(1-8)$ & $1(0-5)$ & 0.395 \\
\hline
\end{tabular}

Table 4. Relationship between experimental parameters and working conditions

\begin{tabular}{lcccc}
\hline & RMQ score & NPDI score & lowback-VAS & neck-VAS \\
\hline Weekly working hour & $r=0.049$ & $r=0.033$ & $r=-0.009$ & $r=0.122$ \\
& $p=0.486$ & $p=0.638$ & $p=0.897$ & $p=0.083$ \\
Daily working hour & $r=0.007$ & $r=-0.007$ & $r=-0.027$ & $r=0.105$ \\
& $p=0.924$ & $p=0.920$ & $p=0.721$ & $p=0.137$ \\
Duration of work while sitting (min) & $r=-0.188$ & $r=-0.271$ & $r=-0.099$ & $r=-0.070$ \\
& $p=0.008$ & $p=0.000$ & $p=0.168$ & $p=0.331$ \\
Duration of work while standing (min) & $r=0.252$ & $r=0.334$ & $r=0.200$ & $r=0.279$ \\
& $p=0.000$ & $p=0.000$ & $p=0.005$ & $p=0.000$ \\
1:RMQ: Roland Morris Lowback Pain and Disability Questionnaire, 2: NPDI: Neck Pain and Disability Index VAS: Visual Analog Scale &
\end{tabular}


LBP prevalence in dentistry were estimated to vary between $37 \%$ and $53 \%(1,11-13)$. In the study presented here the corresponding estimate was higher (61\%). Estimates of prevalence of neck pain in dentists in other studies similar to our results $(14,15)$ however some have been as high as $44 \%$ (12) as compared to ours (34\%).

The working positions such as standing or sitting, which the denist has to maintain during treatment of the patient can adversely affect the back and the neck (16). Investigations using portable ergonomic devices have shown that dentists generally spend half of the working time with their head bent down while sitting, and complain of neck pain (17). In another study, it has been shown that prolonged working with the neck in flexion in excess of 30 degrees causes neck pain (18). In the present study, despite the weakness of the correlations, working while standing appears to be worse than working while sitting in terms of the investigated outcomes. Because, a correlation was observed between the duration of work while standing and back and neck pain. Whereas an inverse correlation was observed between the duration of work while sitting and back and neck pain. Although neck flexion during work, sitting or standing, have been experimentally observed in this study, measurements of the angles have not been made (Figures 2 and 3). According to our observations, the neck postures when working at a sitting position were more neutral than those postures while standing. While working in standing

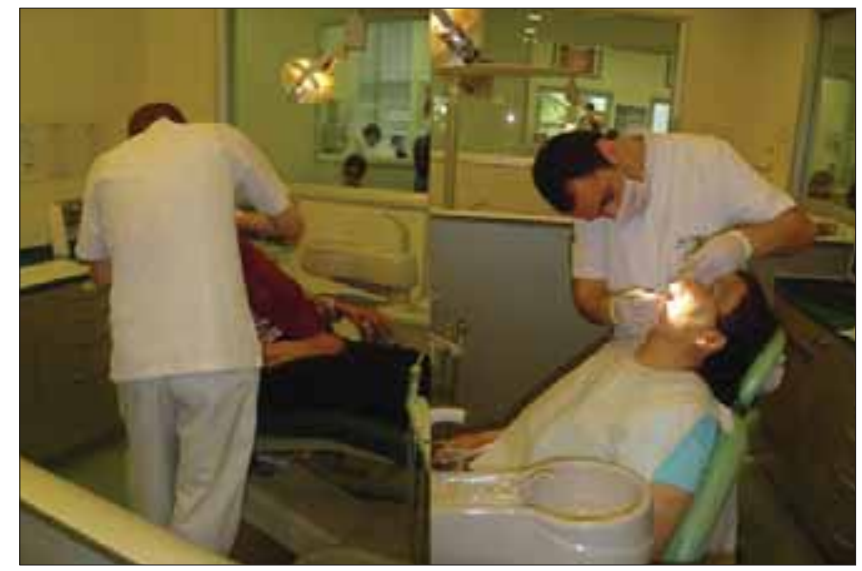

Figure 3. Working posture while standing

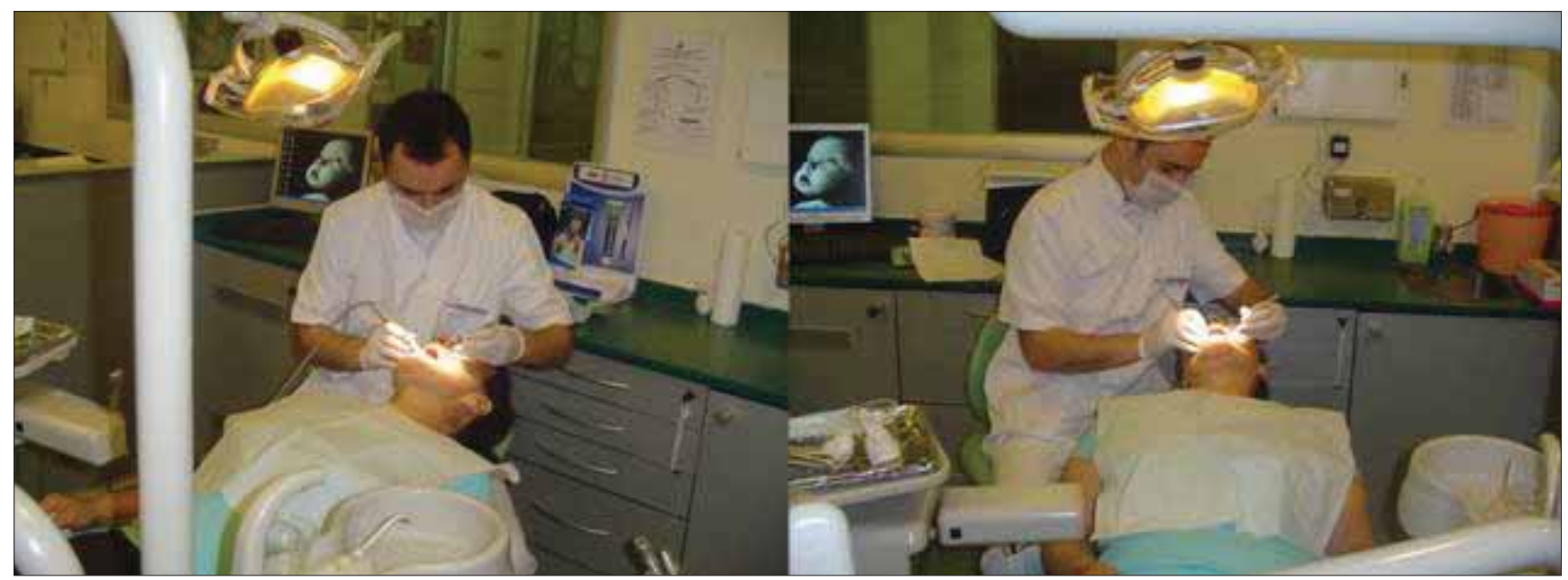

Figure 2. Working posture while sitting

Table 5. Relationship between working conditions and frequency of low back pain and neck pain in some positions

\begin{tabular}{lcccccc}
\hline & $\begin{array}{c}\text { Frequency of } \\
\text { LBP while } \\
\text { standing }\end{array}$ & $\begin{array}{c}\text { Frequency of } \\
\text { LBP while } \\
\text { sitting }\end{array}$ & $\begin{array}{c}\text { Frequency of } \\
\text { LBP while } \\
\text { walking }\end{array}$ & $\begin{array}{c}\text { Frequency of } \\
\text { neck } \\
\text { stiffness }\end{array}$ & $\begin{array}{c}\text { Frequency of } \\
\text { neck pain } \\
\text { while looking } \\
\text { upward- } \\
\text { downward }\end{array} \begin{array}{c}\text { Frequency of } \\
\text { neck pain } \\
\text { during work } \\
\text { above the } \\
\text { level of head }\end{array}$ \\
\hline Weekly working & $r=0.153$ & $r=0.032$ & $r=0.178$ & $r=-0.110$ & $r=0.110$ & $r=0.110$ \\
hour & $p=0.029$ & $p=0.652$ & $p=0.011$ & $p=0.684$ & $p=0.117$ & $p=0.118$ \\
Daily working & $r=0.108$ & $r=0.009$ & $r=0.159$ & $r=0.021$ & $r=0.112$ & $r=0.087$ \\
hour & $p=0.124$ & $p=0.902$ & $p=0.023$ & $p=0.764$ & $p=0.109$ & $p=0.214$ \\
Duration of work & $r=-0.146$ & $r=-0.099$ & $r=-0.096$ & $r=-0.025$ & $r=-0.097$ & $r=-0.046$ \\
while sitting (min) & $p=0.041$ & $p=0.166$ & $p=0.180$ & $p=0.722$ & $p=0.173$ & $p=0.513$ \\
Duration of work & $r=0.310$ & $r=0.171$ & $r=0.240$ & $r=0.241$ & $r=0.308$ & $r=0.258$ \\
while standing (min) & $p=0.000$ & $p=0.018$ & $p=0.001$ & $p=0.001$ & $p=0.000$ & $p=0.000$ \\
\hline LBP: low back pain & & & & & &
\end{tabular}


position, both the back and the neck postures were more asymmetric and at extremes of flexion, or, in other words, in ergonomically inappropriate positions.

In this study it was observed that as the daily and weekly working hours increased, the complaints of LBP increased. It has been thought that prolonged maintanance of an inappropriate body position while working in a limited area may impose excess loading on the spine.

Recent studies have shown no effect of demographic characteristics of dentists on their musculoskeletal complaints $(4,19,20)$. In the present study, the BMI values were found to be within normal limits, incidence of smoking habit was low, and regular physical exercise was quite common, such that it can be thought that the investigated experimental population did not carry personal risk factors for musculoskelatal disorders. The effect of age was investigated by grouping and comparing the experimental subjects according to age below and above 25 years. Only the NPDI scores were found to be higher in the higher age group. This result is similar to those reported by Augustson et al. (21) and Alexopoulos et al. (5), and can be thought to arise from having worked for longer years in dental practice.

In accordance with the results of Alexopoulos et al. (5), there was no difference among the areas of specialistion of the dentists interms of low back pain and neck pain. It has been thought that this is due to lack of significant differences between different specialist groups with respect to postures adopted at work, the duration of work and the demographic details. However, a definite generalisation is not possible as the numbers of specialists in each group were not high enough to support such a conclusion.

One limitation of this study is the lack of objective measurement methods. Taking video recordings of neck flexion, shoulder elevation, upper extreme abduction, angle of body anteflexion and lateral flexion while the dentist is working, in order to make measurements on the images recorded, should establish the relationship between posture and the presence of LBP and neck pain. Another limitation of the study could be the relatively small numbers of the subjects when compared to other studies. It is also thought that individual psychological properties, such as stress intolerance, which would be expected to contribute to incidence and intensity of locomotor pain needs to be included in future studies. Looking at the mean age of the experimental population of this study, significantly young people have been investigated. Inclusion in future research of denists with much longer background at work should contribute to accumulation of more meaningful and probably more variable results.

\section{Conclusion}

It can be concluded that work duration and working posture are effective in causing back and neck pain in the staff of the schools of dental medicine. According to the results of this study, working while sitting is more favourable and recommendable than working while standing. In any future work, evaluation of the postural faults at work in detail should provide the basis for recommending working at more suitable postures to avoid locomotor problems. Also, the education of dental students on ergonomics and postural exercises while training should be useful in this respect.

\section{Conflict of Interest}

No conflict of interest is declared by authors.

\section{References}

1. Szymanska J. Disorders of the musculoskeletal system among dentisits from the aspect of ergonomics and prophylaxis. Ann Agric Environ Med 2002;9: 169-73.

2. Armstrong TJ, Lifshitz Y. Evaluation and design of jobs for control of cumulative trauma disorders. In: Industrial hygenie science series: Egonomic interventions to prevent musculoskeletal injuries in industry. Cheksea: Lewis, 1987: 73-87.

3. Diakow PRP, Cassidiy JD. Back pain in dentists. J Manipulative Physiol Ther 1984; 7: 85-8.

4. Al Wassan KA, Almas K, Al Shethri SE, Qahtani Al. Back and neck problems among dentists and dental auxillaries. J Contemp Dent Pract 2001; 2: 17-30.

5. Alexopoulos EC, Stathi IC, Charizani F. Prevalance of musculoskeletal disorders in dentists. BMC Musculoskeletal Disorders 2004; 5: 16.

6. Yee T, Crawford L, Harber P. Work environment of dental hygienists. J Occup Environ Med 2005; 47: 633-9.

7. Vernon H, Mior S. The Neck Disability Index: A study of reliability and validity. J Manipulative Physiol Ther 1991; 14: 409-15.

8. Kose G, Hepguler S, Atamaz F, Oder G. A comparison of four disability scales for Turkish patients with neck pain. J Rehabil Med. 2007 May; 39: 358-62.

9. Roland M, Morris R. A study of the natural history of back pain. Part I: development of a reliable and sensitive measure of disability in low-back pain. Spine 1983; 8: 141-4.

10. Küçükdeveci AA, Tennant $A$, Elhan $A H$, Niyazoglu $H$. Validation of the Turkish version of the Roland-Morris Disability Questionnaire for use in low back pain. Spine 2001; 26 (24): 2738-43.

11. Ratzon NZ. Musculoskeletal symptoms among dentists in relation to work posture. Work 2000; 15: 153-8.

12. Finsen L, Christensen H, Bakke M. Musculoskeletal disorders among dentists and variation in dental work. Applied Ergonomic 1998; 29: 119-25.

13. Lehto TU, Helenius HY, Alaranta HT. Musculoskeletal symptoms of dentists assessed by a multidisciplinary 
approach. Community Dent Oral Epidemiol 1991; 19: 38-44.

14. Milerad E, Ekenvall L. Symptoms of the neck and upper extremity in dentists. Scand J Work Environ Health 1990; 16: 129-34.

15. Fish DR, Norris-Allen DM. Musculoskeletal disorders in dentists. N Y State Dent J 1998; 64: 44-8.

16. Rundcrantz BL. Pain and discomfort in the musculoskeletal system among dentists. Swed Dent J Suppl 1991; 76: 1-102.

17. Rolander $B$, Karsznia A, Jonker D, Oberg $T$, Beliner $A L$. Percieved contra observed physical work load in Swedish dentists. Work 2005; 25: 253-62.
18. Chaffin DB. Localized muscle fatigue-Definition and measurement. J Occup Med 1973; 15: 346-54.

19. Marshall ED, Duncombe LM, Robinson RQ, Kilbreath SL. Musculoskeletal symptoms in New South Wales dentists. Aust Dent J 1997; 42: 240-6.

20. Chowanadisai S, Kukiattrakoon B, Yapong B, Kedjarune U, Leggat PA. Occupational health problems of dentists in southern Thailand. Int Dent J 2000; 50: 36-40.

21. Augustson TE, Marken T. Musculoskeletal problems among dental health personnel. A survey of the public dental health services in Hordaland. Tidsstir Nor Laegeforen 1996; 30: $2776-80$ 